\title{
FOSZFOR ALAPÚ ÉGÉSGÁTLÓKKAL ELLÁTOTT, SZÉNSZÁL ERŐSÍTÉSŰ KOMPOZITOK ÉGHETŐSÉGI ÉS MECHANIKAI VIZSGÁLATA
}

\section{MECHANICAL AND FLAME RETARDANT FEATURES OF CARBON FIBRE REINFORCED COMPOSITES WITH PHOSPHORUS BASED FLAME RETARDANTS}

Tóth Levente Ferenc

\author{
Budapesti Müszaki és Gazdaságtudományi Egyetem, Gépészmérnöki Kar, \\ Polimertechnika Tanszék, H-1111 Budapest, Müegyetem rkp. 3., \\ levente8912@gmail.com
}

\begin{abstract}
In our research carbon fibre reinforced composites were made with AP422 and RDP flame retardant substance. Their mechanical features were measured with tensile and three-point bending tests. To compare the flame retardancy of the samples UL94 and LOI investigation were applied. The flame retardancy and mechanical features of carbon fibre reinforced composites were examined in function of the type and the concentration of the applied fire retardant substance.
\end{abstract}

Keywords: composite, carbon fiber, flame retardant, LOI, UL94.

\section{Összefoglalás}

Kutatómunkánk során szénszál erősítésű, AP422 és RDP égésgátlóval ellátott kompozitokat készítettünk el. Megmértük a minták mechanikai jellemzőit szakító-, és hárompontos hajlító vizsgálatokkal. A kompozitok éghetőségének összehasonlításához UL94 és LOI vizsgálatot alkalmaztunk. A próbatestek éghetőségi és mechanikai jellemzői a felhasznált égésgátló adalékanyagok típusának és koncentrációjának függvényében lettek vizsgálva.

Kulcsszavak: kompozit, szénszál, égésgátló, LOI, UL94.

\section{Rövidítések}

E: epoxi

EH: epoxi + hagyományos szénszál

EHAP1: epoxi + hagyományos szénszál + AP 422 égésgátló (a minta $1 \mathrm{~m} / \mathrm{m} \%$ foszfort tartalmaz)

EHAP2: epoxi + hagyományos szénszál + AP 422 égésgátló (a minta $2 \mathrm{~m} / \mathrm{m} \%$ foszfort tartalmaz)

EHAP3: epoxi + hagyományos szénszál + AP 422 égésgátló (a minta $3 \mathrm{~m} / \mathrm{m} \%$ foszfort tartalmaz)
EHAP4: epoxi + hagyományos szénszál + AP 422 égésgátló (a minta $4 \mathrm{~m} / \mathrm{m} \%$ foszfort tartalmaz)

EHAP5: epoxi + hagyományos szénszál + AP 422 égésgátló (a minta $5 \mathrm{~m} / \mathrm{m} \%$ foszfort tartalmaz)

EHF1: epoxi + hagyományos szénszál + folyadék (RDP) égésgátló (a minta $1 \mathrm{~m} / \mathrm{m} \%$ foszfort tartalmaz)

EHF2: epoxi + hagyományos szénszál + folyadék (RDP) égésgátló (a minta $2 \mathrm{~m} / \mathrm{m} \%$ foszfort tartalmaz) 
EHF3: epoxi + hagyományos szénszál + folyadék (RDP) égésgátló (a minta $3 \mathrm{~m} / \mathrm{m} \%$ foszfort tartalmaz)

EF1: epoxi + folyadék (RDP) égésgátló (a minta $1 \mathrm{~m} / \mathrm{m} \%$ foszfort tartalmaz)

EF2: epoxi + folyadék (RDP) égésgátló (a minta $2 \mathrm{~m} / \mathrm{m} \%$ foszfort tartalmaz)

EF3: epoxi + folyadék (RDP) égésgátló (a minta $3 \mathrm{~m} / \mathrm{m} \%$ foszfort tartalmaz)

EF4: epoxi + folyadék (RDP) égésgátló (a minta $4 \mathrm{~m} / \mathrm{m} \%$ foszfort tartalmaz)

EF5: epoxi + folyadék (RDP) égésgátló (a minta $5 \mathrm{~m} / \mathrm{m} \%$ foszfort tartalmaz)

\section{Bevezetés}

Kutatásunk során kétféle égésgátolt adalékanyaggal (AP 422 és RDP) ellátott mintákat hasonlítottunk össze egymással. Az AP 422-vel ellátott próbatestek esetén a foszfortartalmat 1 és $5 \mathrm{~m} / \mathrm{m} \%$ között változtattuk, míg az RDP-t tartalmazóknál 1 és 3 $\mathrm{m} / \mathrm{m} \%$ között. Ennek az oka, hogy az RDP folyadékkal égésgátolt mintáknál a 4, illetve $5 \mathrm{~m} / \mathrm{m} \%$ foszfort tartalmazó kompozitok használatra alkalmatlanok voltak, mivel kézzel könnyedén hajlíthatónak bizonyultak. Ennek oka, hogy ezeknél a mintáknál az ekkora foszfortartalom biztosításához a gyantához képest 40 vagy $50 \mathrm{~m} / \mathrm{m} \%$ inert folyadékot kellett a mátrixanyaghoz kevernünk, amely jelentős lágyító hatással bír.

\section{Felhasznált anyagok}

Mátrixanyagként MR-3012 típusú epoxi gyantát használtunk, amelyhez MH-3111 típusú térhálósítószert kevertünk.

Erösítőanyagként

unidirekcionális Zoltek Panex 35 UD300 kötött kelmét alkalmaztunk, ezt nevezzük a továbbiakban hagyományos szénszálnak.

Ammónium-polifoszfát (Exolit AP 422) égésgátló adalékanyag, amely $32 \mathrm{~m} / \mathrm{m} \%$ foszfort tartalmaz, gyártója a Clariant International Ltd [1].

Reofos RDP (rezorcin bisz (difenilfoszfát), F), folyékony halmazállapotú égésgátló adalékanyag, ami 10 m/m\% foszfort tartalmaz, gyártója a Chemtura Corporation [2].

Az égésgátló adalékanyagokkal kapcsolatban fontos megemlíteni, hogy az egyes mintákhoz annyi égésgátlót tettünk, hogy a szükséges foszfor tartalmat biztosítani tudjuk. Tehát például EF2 minta esetén (folyékony halmazállapotú égésgátlóval (RDP) ellátott epoxi gyanta $2 \mathrm{~m} / \mathrm{m} \%$ foszforral) a gyantához $20 \mathrm{~m} / \mathrm{m} \%$ égésgátlót adtunk.

\section{Súrüség és száltartalom vizsgá- lat}

Összesen 9 típusú UD erősítőanyaggal ellátott minta sürüségét és száltartalmát mértük meg, amiket az 1. táblázat mutat be.

A sürüség minden minta esetében 1,479 és $1,536 \mathrm{~g} / \mathrm{cm} 3$ közötti értéket vett fel. A térfogatszázalékban kifejezett száltartalom értéke 43,86 V/V\% és 49,95 V/V\% között mozog minden minta esetében.

1. táblázat. Az elkészitett kompozitok sürüsége és térfogatban kifejezett száltartalma

\begin{tabular}{|c|c|c|}
\hline Típus & Sürüség & Száltartalom \\
\hline EH & 1,527 & 49,56 \\
\hline EHAP1 & 1,526 & 47,74 \\
\hline EHAP2 & 1,522 & 46,91 \\
\hline EHAP3 & 1,479 & 43,86 \\
\hline EHAP4 & 1,547 & 46,73 \\
\hline EHAP5 & 1,536 & 44,18 \\
\hline EHF1 & 1,516 & 46,00 \\
\hline EHF2 & 1,556 & 49,95 \\
\hline EHF3 & 1,500 & 44,72 \\
\hline
\end{tabular}

\section{Statikus vizsgálatok}

Statikus vizsgálatnak összesen kilenc különböző mintát vetettünk alá, a mérések célja, hogy a két égésgátló adalékanyagnak a kompozitok mechanikai tulajdonságaira gyakorolt hatását felderítsük.

\subsection{Hárompontos hajlító vizsgálat}

A hajlítószilárdság mind RDP, mind APP égésgátló esetében csökkenő tendenciát mutat, az EHAP5 és EHF3 minták hajlí- 
tószilárdságának esése az $\mathrm{EH}$ referenciához képest rendre 16 és 46\%. Ennek magyarázata, hogy az égésgátlók hibahelyként vannak a gyantarendszerben, így gyengítik a minták mechanikai tulajdonságait. Mindkét típusú adalékanyag hozzáadásával nő a próbatestek deformálhatósága, ezt a minták rugalmassági moduluszának csökkenéséből láthatjuk. A minták hajlítószilárdságait és rugalmassági moduluszukat az $\mathbf{1}$. és a $\mathbf{2}$. ábra mutatja be.

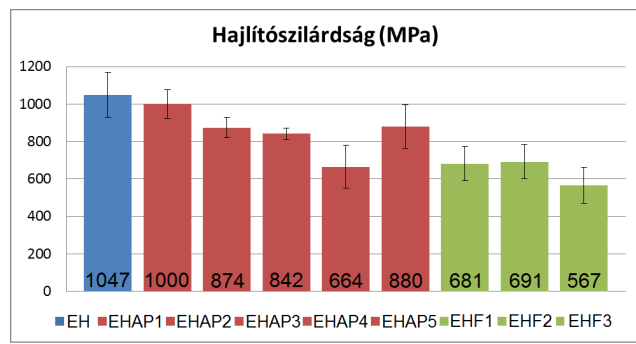

1. ábra. Az égésgátló adalékanyaggal ellátott minták hajlitószilárdsága

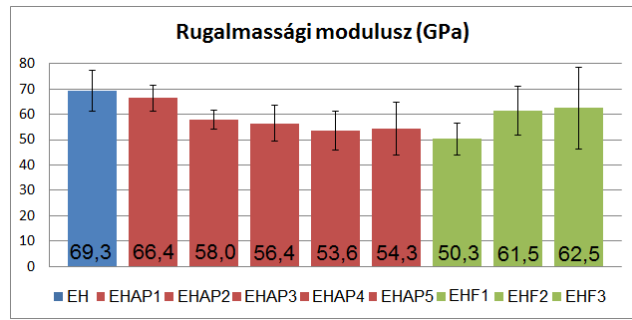

2. ábra. Az égésgátló adalékanyaggal ellátott minták rugalmassági modulusza

\subsection{Szakító vizsgálat}

A szakító vizsgálatot video extenzométeres nyúlásméréssel végeztük el. A minták szakítószilárdsága jellemzően nem változott, a különbségek többsége szóráshatáron belül mozgott. Az égésgátolt minták rugalmassági modulusza viszont itt is csökkent a referencia $\mathrm{EH}$ típusú kompozithoz képest, de az égésgátlók fajtája és koncentrációja nem befolyásolja jelentősebben.
A minták szakítószilárdágait és rugalmassági moduluszukat a 3 . és a 4. ábra mutatja meg.

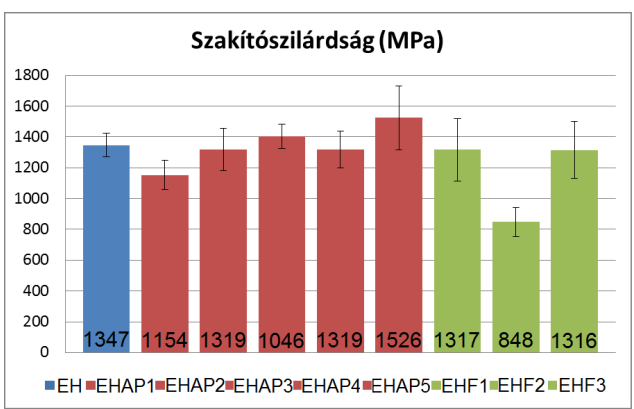

3. ábra. Az égésgátló adalékanyaggal ellátott minták szakitószilárdsága

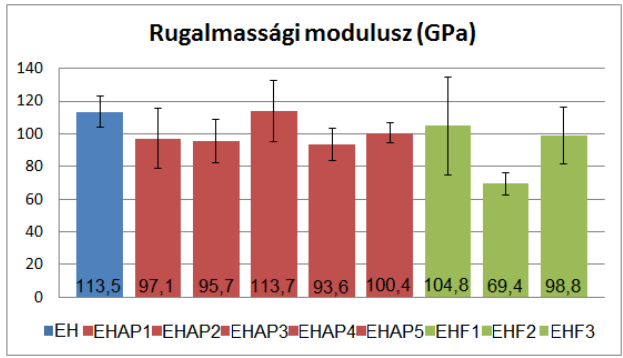

4. ábra. Az égésgátló adalékanyaggal ellátott minták rugalmassági modulusza

\subsection{Folyékony égésgátlóval (RDP) el- látott gyanták összehasonlítása hárompontos hajlító vizsgálattal}

A vizsgálat során folyékony halmazállapotú RDP égésgátlóval ellátott 1, 2, 3, 4, 5 $\mathrm{m} / \mathrm{m} \%$ foszfort tartalmazó epoxigyanták lettek összehasonlítva az égésgátló adalékanyagot nem tartalmazó referencia epoxigyantával.

Csak az E, EF1 és EF2 jelü minták törtek el hajlításkor, a 3 vagy több $\mathrm{m} / \mathrm{m} \%$ foszfort tartalmazók nem. Az EF4 és EF5 jelü mintáknál kézzel hajlítva is egyértelmüen tapasztalható volt, hogy gumiszerüen viselkedtek. A vizsgálatot úgy végeztük el, hogy a minták maximum $40 \mathrm{~mm}$ deformációját engedje meg a rendszer (ez jóval na- 
gyobb, mint a határhajlító feszültségnél fellépő deformáció, azonban így lehetőség volt a nagy lehajlást elviselö gyanták jobb összehasonlítására), az alátámasztási hosszt 64 mm-re állítottuk.

Az E, EF1, EF2, EF3, EF4 és EF5 mintáknál a maximális feszültség rendre 4,1 ; 3,$9 ; 3,4 ; 1,5 ; 0,4$ és $0,1 \mathrm{MPa}$, míg az E, EF1 és EF2 elnevezésű próbatesteknél a törés rendre 8,$3 ; 18,7$ és $41,4 \%$ deformációnál következett be. Az EF3, EF4 és EF5 jelzésü minták pedig nem törtek el, a $40 \mathrm{~mm}$-re beállított maximális deformációt elérték. Ez azt jelenti, hogy 40/64, vagyis 0,625 $62,5 \%$ - deformációt szenvedtek el. A hajlítási görbéket az 5. ábra szemlélteti.

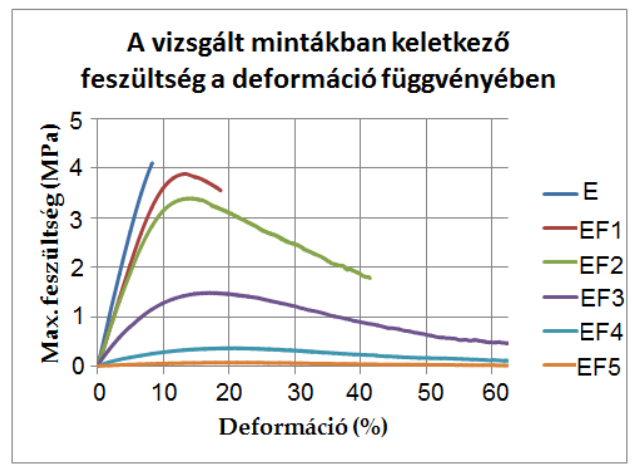

5. ábra. Az RDP égésgátlóval ellátott minták hajlitási görbéi

\section{5. Éghetőségi vizsgálatok}

\subsection{UL94 vizsgálat}

A 2. táblázatból látható, hogy az RDP égésgátló minden vizsgált mintája HB besorolást szerzett, viszont az AP 4224 és 5 $\mathrm{m} / \mathrm{m} \%$-os mintája V-0 kategóriába került.

Egyik minta sem égett csöpögve, nem gyújtotta meg az alatta elhelyezett vattát.

\subsection{LOI vizsgálat}

RDP égésgátló adalékanyaggal ellátott minták esetében a 2. táblázatból jól látható, hogy az oxigénindex már $2 \mathrm{~m} / \mathrm{m} \%$-nál is elérte a $42 \mathrm{~V} / \mathrm{V} \%$-ot, amit a koncentráció további növelésével sem lépett túl.

Az AP 422-vel ellátott minták esetében kimondható, hogy jelentős javulást csak a 4 , illetve $5 \mathrm{~m} / \mathrm{m} \%$-nál lehetett elérni (38 $\mathrm{V} / \mathrm{V} \%$ ), de ez sem közelíti meg a minimum $2 \mathrm{~m} / \mathrm{m} \%$-os RDP égésgátlóval ellátott minták eredményeit.

2. táblázat. UL94 és LOI vizsgálat eredményei

\begin{tabular}{|c|c|c|}
\hline Típus & UL94 fokozat & $\begin{array}{c}\text { Oxigén index } \\
\text { (V/V\%) }\end{array}$ \\
\hline EH & HB & 33 \\
\hline EHAP1 & HB & 34 \\
\hline EHAP2 & HB & 35 \\
\hline EHAP3 & HB & 36 \\
\hline EHAP4 & V-0 & 38 \\
\hline EHAP5 & V-0 & 38 \\
\hline EHF1 & HB & 35 \\
\hline EHF2 & HB & 42 \\
\hline EHF3 & HB & 42 \\
\hline
\end{tabular}

\section{Következtetések}

Az AP 422 és RDP égésgátlók hatására a szakítószilárdság jelentősen nem változott, a hajlítószilárdság csökkenő tendenciát mutat mindkét égésgátló koncentrációjának növelésekor. A próbatestek rugalmassági moduluszát az adalékanyagok csökkentették.

Égésgátlás szempontjából az EHAP4 és EHAP5 minták eredményei kiemelkedőek, ugyanis V-0 besorolást szereztek, és oxigénindexük 38V/V \%-ot ért el. Az RDP már $2 \mathrm{~m} / \mathrm{m} \%$-ban $42 \mathrm{~V} / \mathrm{V} \%$ oxigénindexet eredményezett. UL94 besorolása viszont maradt változatlanul $\mathrm{HB}$.

\section{Szakirodalmi hivatkozások}

[1] http://www.clariant.com/en/Solutions/Produc ts/2014/03/18/16/31/Exolit-AP-422

(2015. január 11.)

[2] Szolnoki B.: Új, égésgátolt epoxigyanták és kompozitjaik kifejlesztése. PhD értekezés. BME (2014). 